\title{
Globalizaje somos
}

\section{Kee Warner Carrillo ${ }^{1}$}

Accepted: 25 October 2020 / Published online: 23 November 2020 (c) Springer Nature Limited 2020

When I applied for my sabbatical leave in 2019, I proposed to study the transformation of US/Mexico borderlands along a coastline of Sonora in the area of San Carlos that I have visited my whole life. I wanted to better understand the social, cultural and ecological transformations that I had experienced and explore my own role in them. I intended to combine ethnographic study with personal reflection, well-documented narrative with poetry and images, to shed some light on one of the many realities of globalization. I already knew that this was one of the places on Earth that owns me in some fundamental way, but the months that I spent in residence showed me how much more there was to learn about all that surrounded my own experience: the people, the living ecology, the histories, the politics and the cultures. As I strove to understand how I fit into this place that was both far away and close to me, I realized that I was one more agent in an ongoing dialectic that defines borderlands.

Grappling with all of this led me to consider the more personal and formative dimensions that are at work within overarching frameworks of globalization. These seem small against the backdrop of interwoven systems of finance, consumerism, climate change, social networks and cultural production, but this is the terrain where we give shape to meanings, to relationships and to communities that transcend borders. What I dub globalizaje is the active creation of shared social practices and meanings within this space. Considering how, in a matter of weeks, the coronavirus pandemic upended what we had considered indomitable global systems, it is worth reconsidering the potential of these more grassroots forms of globalization. Borderland communities are uniquely prepared to carve new paths forward in this context, because of our healthy skepticism of the mainstream and our history of forging lifeways out of conflict, combination, synthesis and invention. We are defined by this very process, hence the title of this essay: globalizaje somos. After setting the broader historical and geographic stage, I explore globalizaje in San Carlos and consider how it matters through a half dozen interwoven stories from my recent time in the field. We will see that the impacts run in multiple directions; the unifying thread is the action of creating the borderlands, though in circumstances not of our own choosing.

Kee Warner Carrillo

kee.warner@uccs.edu

1 University of Colorado Colorado Springs, Colorado Springs, CO, USA 


\section{Changing borderlands}

Even as President Trump strained to make the US/Mexico border an impregnable wall of steel and cement, it was more fluid than ever, especially when we consider boundaries of language, culture and social practices that surround the line etched into the ground. The change over my lifetime is striking. When I lived in Mexico as a teenager in the 1970s, it felt like such a different world, even though my family origins were on both sides of the border and we passed back and forth at least once a year. Now the crossings are militarized, but the language, the tacos, the money and the human capital are common resources of the growing borderlands that take form in myriad local and individual variations from south to north, from west to east. The reconstruction of the US/Mexico borderland is a cultural transformation that also takes physical and ecological form. The wall and the militarized zone that surround it are the least of it. The borderlands reach out far into the interiors of Mexico and the United States, to the carnicerías of Portland and Chicago, to the Costco's and KFC's of Hermosillo and Cajeme.

When we look at snapshots of a specific place over a long span of time, it is easy to think that change is a steady and incremental shift from one reality to another (Fig. 1).

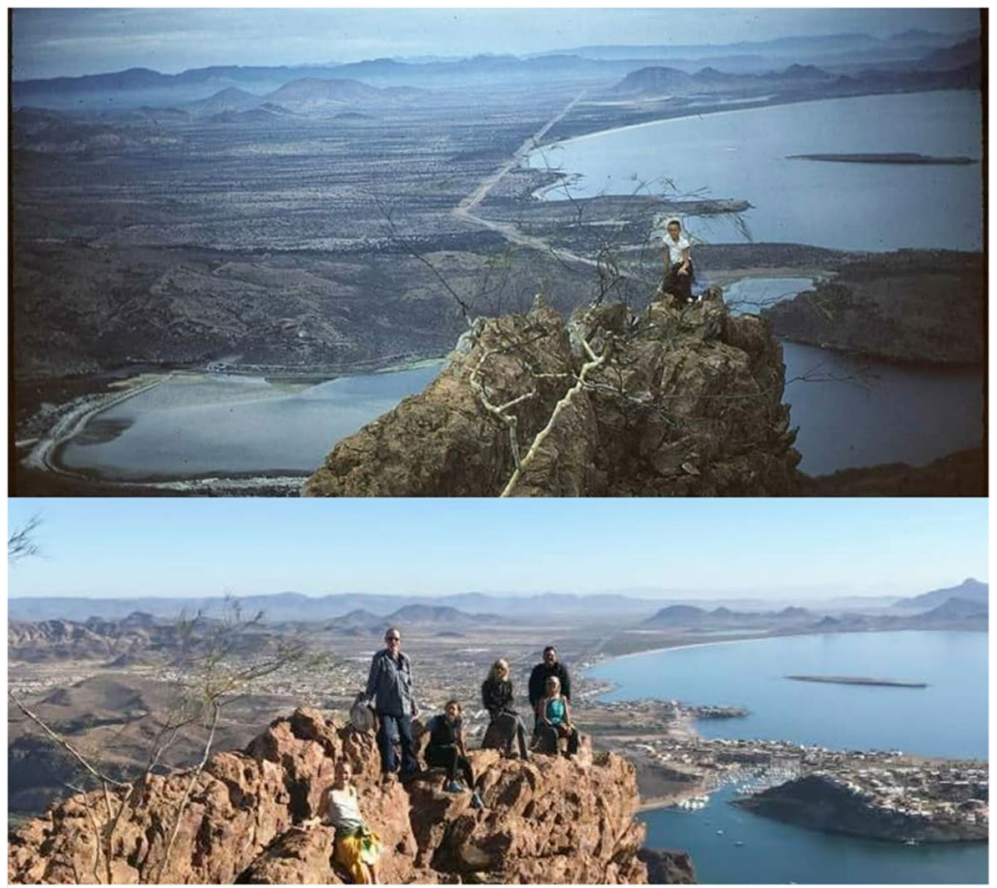

Fig. 1 Photos used with permission from Paul G. Dayton and Kaly A. Warner, all rights reserved 
Take this view of San Carlos from the shoulder of the Tetakawi for instance. In the early shot (top), the coastline in 1956 was linked to the Pan-American Highway by a two-lane road, with fledgling infrastructure evident around the harbor, but there is little else in the surrounding desert. In the sixty years transpired until the second photo (bottom), the coastline was built out, the developed harbor was filled with yachts, and the flatland of Ranchitos were crisscrossed by streets and property lines.

The truth is that development advanced in fits and starts, moving forward into new areas even as other pieces languished and fell back into disuse The self-proclaimed father of San Carlos, Rafael Caballero, began with a grand vision in the early 1960s and established a framework for growth to attract snow bunnies from the north with mechanisms for them to buy real estate despite the restrictions on foreign ownership. Urbanization edged farther into the interior, but left large gaps and ambitious plans undone. Overarching frameworks for globalization first took shape in the form of improved highways and easier border crossings, and then accelerated, with ATMs and on to online banking and Amazon.com.mx. Sometimes development surged forward, as when the filming of Catch-22 in 1969 opened a paved road beyond the Tetakawi peaks. But in other years, it slowed to a crawl, like when mega projects such as the Hotel Presidente, Shangri La Trailer Park and Estero del Soldado stalled out.

As the landscape was transformed, social realities emerged that wove together the lives of gringo retirees with Mexican weekenders from nearby cities with the carpenters and cleaning ladies, the dentists and store owners who made their living by feeding, supplying and serving these short- and long-term residents (Fig. 2).

The enactment of the North American Free Trade Agreement (NAFTA) marked an opening of borders in 1994. And, even though the impact was immediately complicated by a severe devaluation of the Mexican peso and rebellion by the Zapatistas in Southern Mexico, over the following fifteen years, American commercial enterprise spread into Mexico in a big way (Walmart, Costco, Lowe's, and McDonald's),

Fig. 2 Photograph by Kee Warner Carrillo

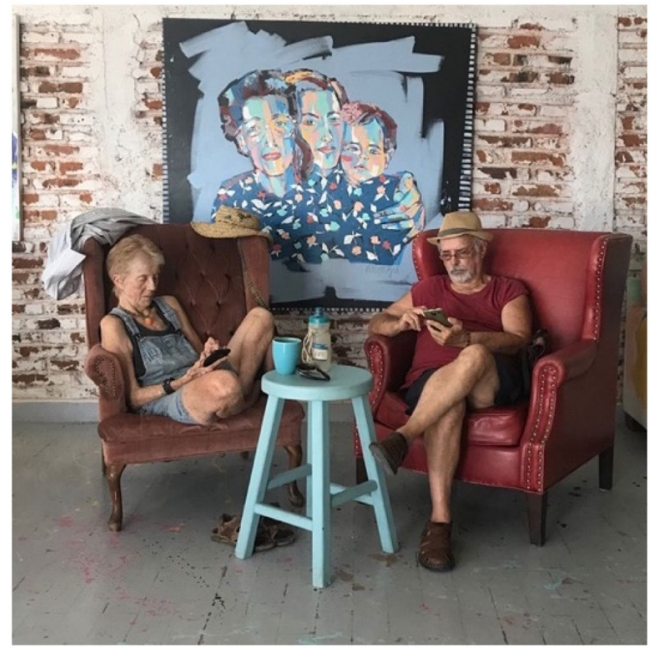


even as Mexican communities grew in size and visibility in the cities and countryside of the United States. Globalization allowed the flow of products, people and information across national borders and an integration of processes that facilitated living in the borderlands.

Visiting San Carlos almost every year of my life with the family that I hold closest, sharing days and nights camped where the desert meets the sea, gave me a deep connection with this place. Yet, even though my family roots in Sonora and Arizona are deep, my feeling of belonging only went so far. I cared about the environmental damage and social inequities that I saw, but I was not there long enough at any stretch to do much more, and I was not sure whether it was my place to be involved. As the world drew closer together and I saw the globalized community that San Carlos was becoming, I reexamined these assumptions and the possibilities that globalizaje might unfold. I offer here some glimpses from my sabbatical field notes (Fig. 3).

As built environments and ecosystems were transformed, the people of the border had to construct identities and communities in these altered states through globalizaje.

This neologism derives from mestizaje, a concept that is integral to Chicanx identity in United States. Chicanx advocated mestizaje against the idea that being of "mixed" culture is lesser than being a "real" American or a "real" Mexican. Instead, being Chicanx represented a willful cultural synthesis containing space for every blend of Hispanic, Native and American culture. This entailed individual processes of self-exploration, but within the context of collective meaning-making of communities and in grounded relationship with certain places on the Earth. Just as mestizaje challenged static categories of racial and national identity, globalizaje challenges the dominant currents of globalization that are driven by commodification,

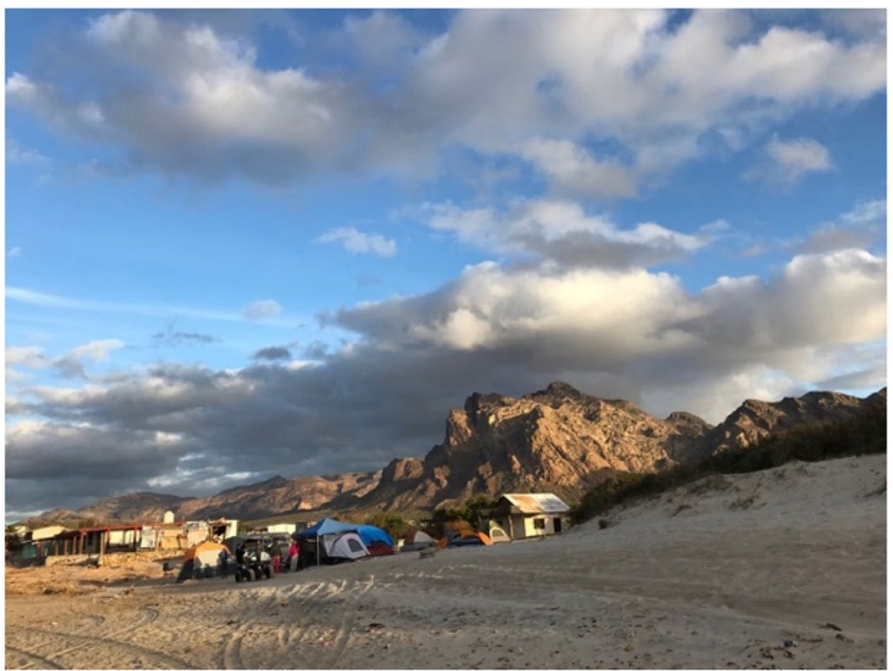

Fig. 3 Photograph by Kee Warner Carrillo 
markets and the institutional practices of modernity. Globalizaje is the active creation of communities and identities that are rooted in place within the transborder context. In this essay, I consider local people who take advantage of these altered terrains and global resource to create livelihoods and to advance a variety of concerns such as environmental protection, employment opportunity, civic engagement and cultural development. Here are some glimpses and reflections from my sabbatical field notes.

\section{Globalizaje tales}

We were walking toward the mouth of the estuary beyond Condominios Pilar in the dimming light of early evening when Kate spotted something bobbing in the tide some twenty feet from shore and asked, "Is that a sea turtle?" (Fig. 4).

The form was hard to distinguish, but it seemed to be moving slightly in the waves. I waded out to get a closer look and made out the shape of a turtle facing out to sea and poking its neck while blinking its large jet eyes. Not knowing what else to do, I left it floating there and we continued our walk. When we headed back, half an hour later, we found the turtle lying inert at the edge of the lapping tide. We lamented that the first turtle we had ever seen in all these years was already dead on the sand. I quickly texted my brother, Danny, who had returned to Colorado a few weeks earlier. After attending a volunteer training in San Carlos for turtle rescue, he had told me that volunteers were supposed to report any nests or sightings, rather than intervene in any way. Within minutes, he texted me back to say that Elsa from the turtle rescue organization would be out soon to examine the turtle and see what had happened. In the time it took to walk back to our car, the information had traveled from me to Colorado then back to San Carlos, to Colorado, and back to my phone.

Fig. 4 Photograph by Kee Warner Carrillo

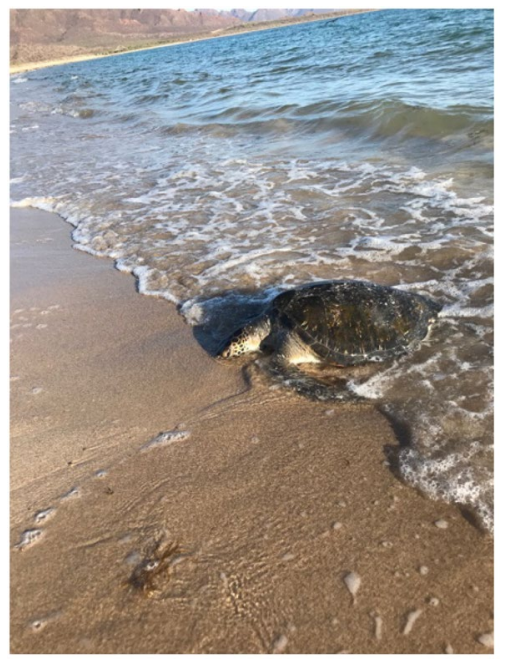


A few weeks later, Kate and I met up with Elsa to learn more about the organization that she helped create and the network that made possible this ricochet of information in the common interest of protecting the sea turtles (Fig. 5). Elsa said that the black sea turtle that we found was killed by a blow to its neck, from either a boat or a blunt object. She went on to tell us how she, a wildlife veterinarian, and her husband, a biologist, had immediately become involved in rescuing injured animals in the Sea of Cortez after moving there from Mexico City twenty years before. Several competing nonprofit organizations founded by expats had already taken up the cause of saving the turtles, but often their understanding of the ecology and strategies were at odds with one another. The US and Canadian volunteers who were involved were dedicated and knowledgeable but were not trained wildlife biologists. Some advocated removing the turtle eggs from the nests so they could be incubated in a controlled environment and then released as hatchlings, while others dedicated themselves to standing vigil over the nesting sites. Their relationship with the federal agencies charged with protecting the environment reflected the deep skepticism many expats held toward Mexican institutions.

As Mexican scientists, Elsa and her husband, Janitzio, were well familiar with the body of environmental law and the operation of regulatory agencies (Fig. 6). They brought the competing turtle rescue NGOs to the table and gained their support for a new organization that they would head, the Center for Wildlife Rescue, Rehabilitation, and Research (Centro de Rescate, Rehabilitación e investigación de Fauna Silvestre, CRRIFS). They responded to distress calls concerning marine wildlife, like the one relayed through my brother, which was a great support for understaffed government agencies. They also conducted inventories and other research on the health of marine fauna in their nesting and feeding areas.

Rescue and rehabilitation were sometimes simultaneous, as on the island of San Pedro Nolasco, where they might disentangle a dozen sea lions from fishing line every time they conducted a population survey. Most of the volunteers they

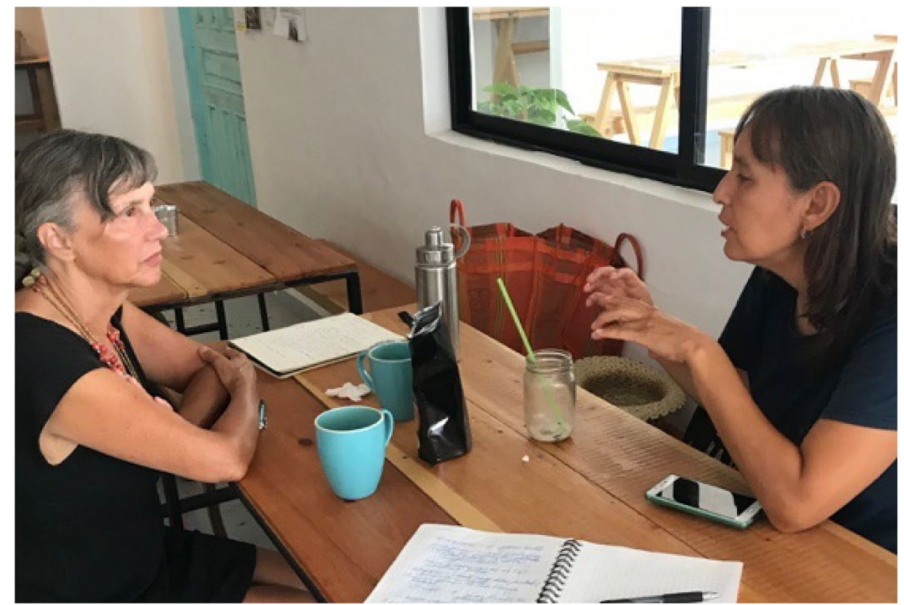

Fig. 5 Photograph by Kee Warner Carrillo 


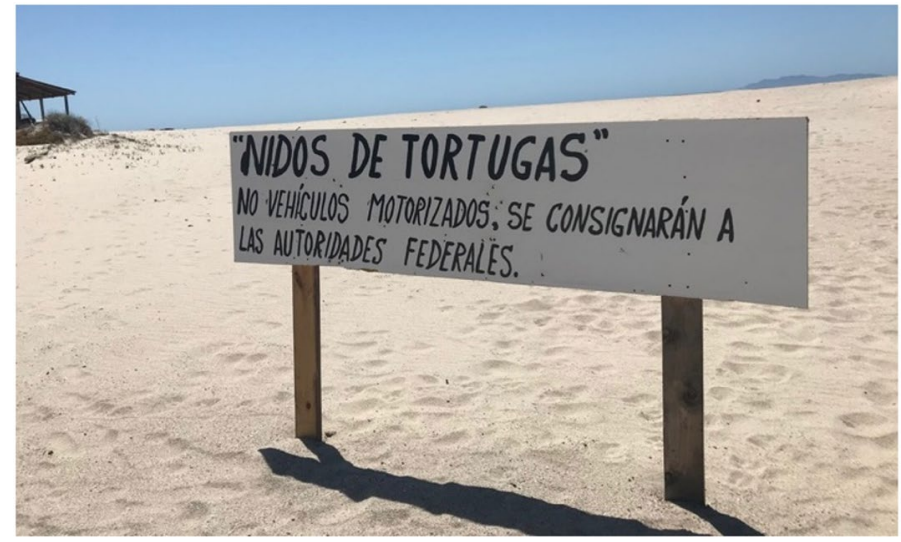

Fig. 6 Photograph by Kee Warner Carrillo

trained were not Mexicans, but CRRIFS was intent on building the participation of local Mexican environmentalists and initiating partnerships with nearby fishing communities. One method was by hiring local fisherman to use their panga boats to help carry out marine surveys of offshore feeding areas. Another was by involving women and youths from fishing villages like La Manga in monitoring wildlife populations and ecological conditions. Environmental degradation was propelled by an array of global demands, from the mass consumption of shrimp to niche markets for luxury goods such as the swim bladders of the endangered totoaba fish, endemic to the Gulf of California. But, defenders of nature also transcended borders to link diverse communities committed to promoting environmental sustainability through globalizaje.

This was not the only way the village of La Manga was involved in globalizaje. It turned out that the women of La Manga were a critical ingredient in the success of the Soggy Peso Bar at the end of Playa Algodones. When Hurricane Marty put the Club Paradiso all-inclusive resort out of business in 2015, the Dutch owners offered Lisa the chance to set up her own business using one of the outbuildings in return for a nominal rent. Lisa had come to San Carlos with Club Med as one of the "gracious organizers" (GOs) who orchestrate activities and lead the fun for their guests, from hiking to kiteboarding to disco dancing on the beach. Originally from Canada, she had spent some years working in Club Meds around Mexico and the Caribbean. When she became pregnant, she knew that her time as a GO would come to an end-raising an infant as a single mom was not accepted as part of that lifestyle. She was able to finish out during Club Med's last year of operation at Sonora Bay and later signed on with Club Paradiso when they bought the resort. After the demise of Club Paradiso and minimal resources, Lisa set out to open a beach bar strung with hammocks and with tables set out in the white sands. She named it "The Soggy Peso" and turned to the young women of La Manga for her workforce. They, too, were young mothers, some of them near destitute and without any formal work experience. The Soggy Peso was open only until 7 p.m., so that Lisa and her staff 
could go home for their second shift of raising children and managing households (Fig. 7).

The Soggy Peso began with a handful of customers, including recreational sailors who would anchor offshore by Isla El Venado and come in by dinghy, but grew steadily and succeeded, even as neighboring ventures came and went on the former grounds of Club Paradiso (Fig. 8).

When Lisa was offered the chance to take over the abandoned kiteboard shack next door, she turned it into the Sunset Grill, a high-end restaurant that would open for sunset, just as Soggy was preparing to close for the day. Sunset Grill was staffed by workers transported in from Guaymas, including locally trained chefs.

The head chef, Miguel grew up learning from his grandpa in San Jose de Guaymas about how to use local herbs for remedies and cooking. He worked his way up to head chef at Sunset and planned to travel beyond Sonora to broaden his understanding of food and build on the exposure to the world that his customers had opened to him. He hiked with us to a canyon hidden in the desert, where a deep pool of water nestles against the cliffs fed by underground streams, and showed us edible plants along the way (Fig. 9).

Though we went there on our own, now the canyon is part of the Rancho Nuevo Parque de Aventura, a new concept of adventure park. Rancho Nuevo is the work of Laura, daughter of one of the ejidatarios who were allocated land in the subdivision of the 13 de Julio ejido. She was promoting guided tours and educational programming with the aim of protecting their seven hundred hectares from development and advocating ecological protection. Rancho Nuevo is on Facebook and is attracting visitors from Mexico City and internationally. Laura was one of the young entrepreneurs who are creating livelihoods that go beyond

Fig. 7 Photograph by Kee Warner Carrillo

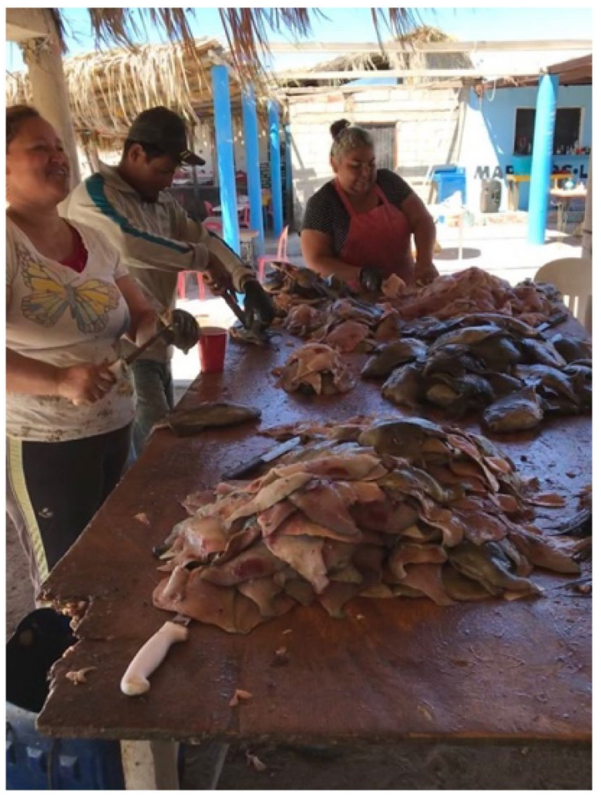




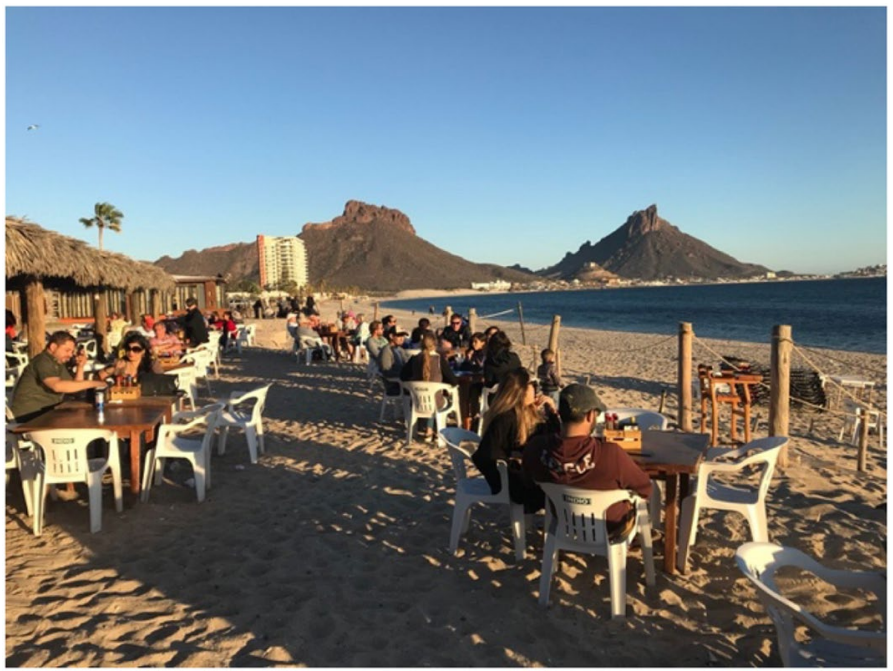

Fig. 8 Photograph by Kee Warner Carrillo

Fig. 9 Photograph by Kee Warner Carrillo

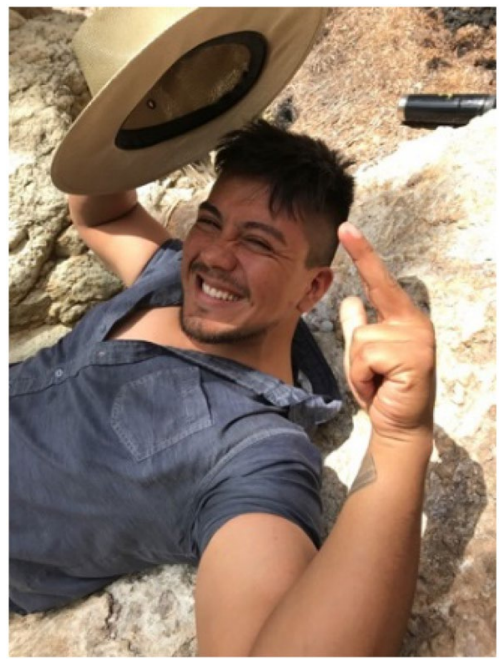

the traditional sun and sea models of tourism. They provided more active physical and educational engagement with the local ecology.

One of Laura's peers, Enrike, had recently been elected as the local comisario, an adviser to the municipal government of Guaymas representing San Carlos and the surrounding rural areas. He was born in Guaymas but spent his teenage years in Los Angeles, where he became fluent in English and the American style of doing things. He started out working for one of the oldest dive shops in San 
Carlos, then branched out on his own with Enrike's Adventures, leading kayak, mountain biking, and hiking trips (Fig. 10).

He was an unexpected choice for comisario because he was neither involved in party politics nor a member of the developer elite in San Carlos. He hoped to challenge the municipality of Guaymas to provide more resources for infrastructure and services in San Carlos, especially considering the tax revenues that were generated by the area. This resonated with the growing number of expats who felt that they received little in return for their annual tax payments-not considering perhaps the needs of the low-paid service workers that made their low-cost lifestyle possible. He also envisioned getting residents and businesses more involved, in the civic style of the United States, in carrying out local improvement projects that were not priorities for the municipality.

Like Enrike, Omar spent some formative years living in the United States. He had already completed his formal education at Mexico's premiere music academy, el Conservatorio Nacional de Música in Mexico City, but to repay the substantial private student loans that he owed, he entered the international work force, beginning with the Princess Cruises cruise line. He knew that he would have to find something more lucrative than dishwasher wages. He wound up in the hands of "la migra" instead and was deported to Tijuana. He stayed along the border until he found another way across and journeyed again to the Northwest, where he did get a job on the fishing boats. There he met Kathy, who was using her degree in natural resources from the University of Michigan to work as an environmental observer on the fishing fleet. Once Omar had paid off his student debts, he bought a car, then a professional keyboard. After they got married in the United States, Omar returned to Mexico to begin the process of "regularizing" his immigration status, and Kathy joined him there.

Throughout all these travels, he kept his music going, playing whenever he had access to a piano, or a guitar, or a ukulele, and learning from the music around

Fig. 10 Photograph by Kee Warner Carrillo

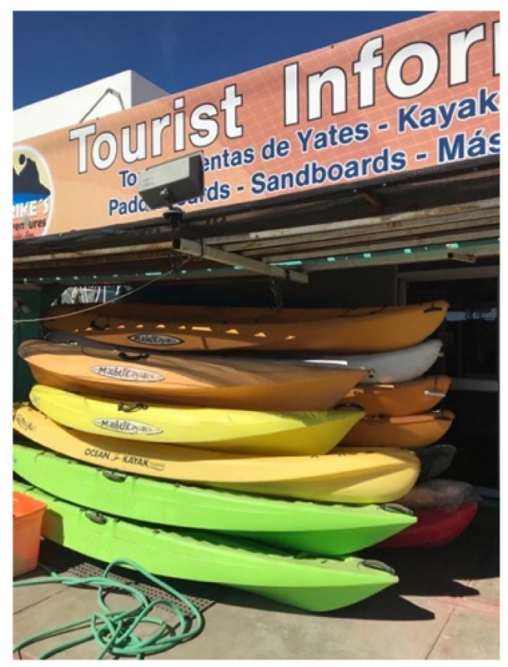


him. After establishing himself in San Carlos with the rock band Utopía, Omar left behind the cranked-up volume and late hours of rock-and-roll to pursue a variety of solo work, new bands and collaborations, developing a solid base of committed fans, many of them expats. One night he would play with Sonora Jazz on the sands of the Sunset Grill (Fig. 11). Another would find him at the pizza bistro, improvising a musical soundtrack to accompany one of the silent movies from his collection. He said to me, "San Carlos has given me a gift that no other place did-not the richest cities of the first world - an opportunity to make a living with the music that I love. The fan base that I have is a real treasure and is a product of this particular type of community" (translated by author).

When I met with him, we were sitting in kids' chairs in the open-air hallway of what once was the Ranchitos Junior High, now repurposed as a community center (Fig. 12). In the classroom beside us, a dozen girls and boys were learning to play steel drums, practicing parts for a piece Omar had arranged and was teaching with two other music instructors. "This is probably the only steel drum orchestra in Mexico, because the drums originate in the Caribbean Islands" (translated by author). A devoted Jimmy Buffet fan living in San Carlos had the idea of creating a steel drum orchestra, and the "Parrot Head" donated a full set of the instruments to the youth orchestra in Guaymas. The instruments were turned over to the community center in Ranchitos when Omar agreed to direct the group. The kids of Ranchitos were not only learning about a culture from another side of the world, they were also giving local culture another face, even as they learned discipline and teamwork that might help them succeed.

These are a few threads of globalizaje that I experienced among so many. In each case, individuals and communities actively engaged in constructing different grounds for their lives and for their futures. They open possibilities in such realms as sustainable tourism, cultural development, education, civic engagement, entrepreneurship, and ecological stewardship.

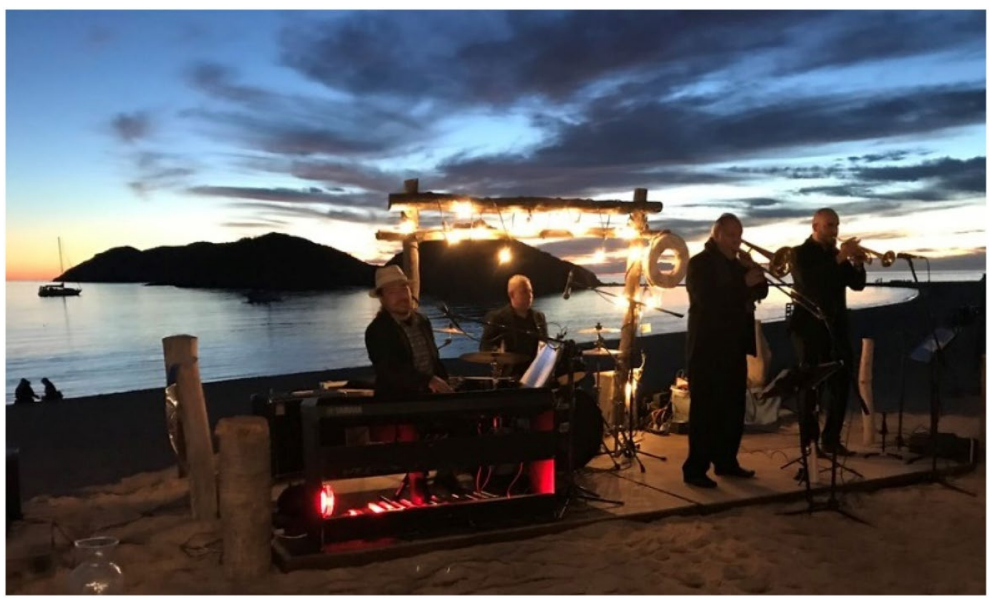

Fig. 11 Photograph by Kee Warner Carrillo 
Fig. 12 Photograph by Kee Warner Carrillo

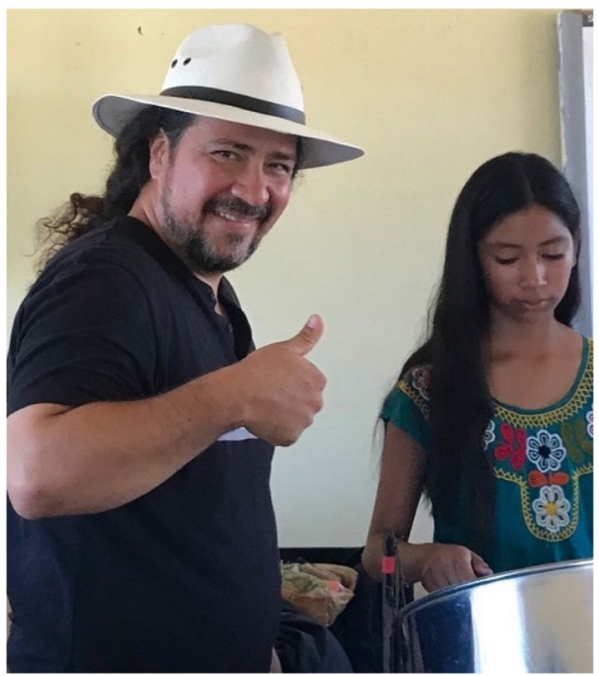

As I learned about what these new compañeros were doing, my own sense of connection, participation, and possibility was likewise altered (Fig. 13). With my sabbatical at an end, I returned to pick up work and life in Colorado; I am still discovering the lasting impacts of this experience, and I am making choices about how this changes who I am. How will my relationships across the borderland grow or languish over time and distance? How will my insights into globalizaje alter my engagement with San Carlos, but also with the life and communities that surround me at present? Within a few short months, the experiences begin to dim and my attention is drawn elsewhere, but separation in time and space are not as complete.

Fig. 13 Photograph by Kate Carduck Warner

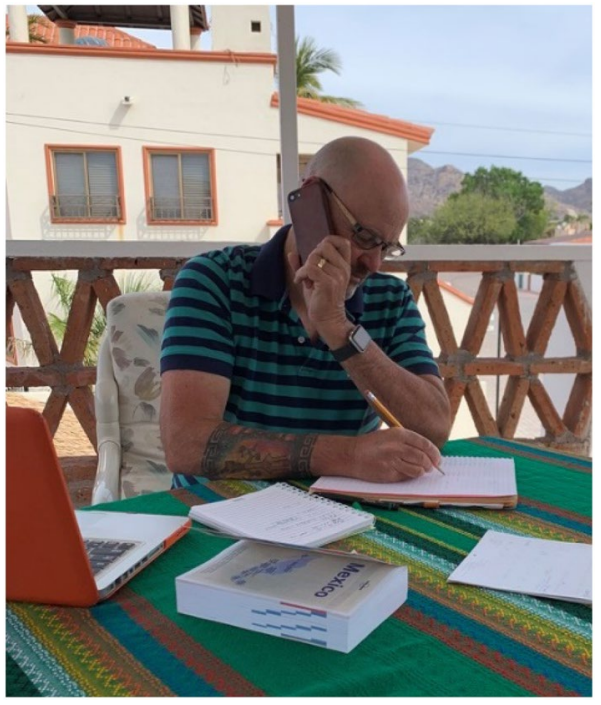


As I write these reflections and have a question, I get an immediate WhatsApp response from Luis the fisherman, or Miguel, or Elsa, or Omar, and I share my explorations with them as I form my words and sentences, in English and Spanish. The world hardly needs another buzzword, but I am curious to learn from the conversations that my reflections about globalizaje may open. The potential benefits may allow resources to flow in new directions and create space for different livelihoods and different ways of knowing. We may transcend the boundaries of local folkways and institutional forms to embrace the jazz of improvisation. As we retreat in the COVID pandemic from the daily interactions that fill our lives, we are learning technologies and practices that may facilitate new levels of transborder community: for example, the email appeal that I just received from my nephew, a leader in a network of Ópatan descendants, including me, who are committed to reclaiming language and culture and who are raising funds for Ópatans in the village of Opodepe, Sonora, where the COVID-19 has created food shortages (Opata Nation/ Nación Opata 2020).

The border is a clear line only in the abstract. In real time and space, borders are more like the boundaries between sea and earth, defined by a rhythm and flows, and ever shifting over longer term (Fig. 14). As Victor Konrad shows, this is not just an artistic notion, but a more suitable scientific model of borders (Konrad 2015). Fixing the borders into something hard requires constant human effort and does not endure. The truth of our borders is more the curve of a ribbon in the breeze, tendrils of water in a river delta, scatterings of shells and sea glass left by receding tides. As Francisco Cantú (Cantú 2018) writes, "the line becomes a river," and Jorge Drexler sings, "somos una especie en viaje, no tenemos pertenencias sino equipaje," or in English, "we are a species on the move, we don't have real belongings, we only have bags that are packed and ready to go" (Drexler 2017, translation by author).

In the end, borders are active constructions that are fundamentally cultural and geopolitical. Rather than taking the border as a literal line in the sand, we should

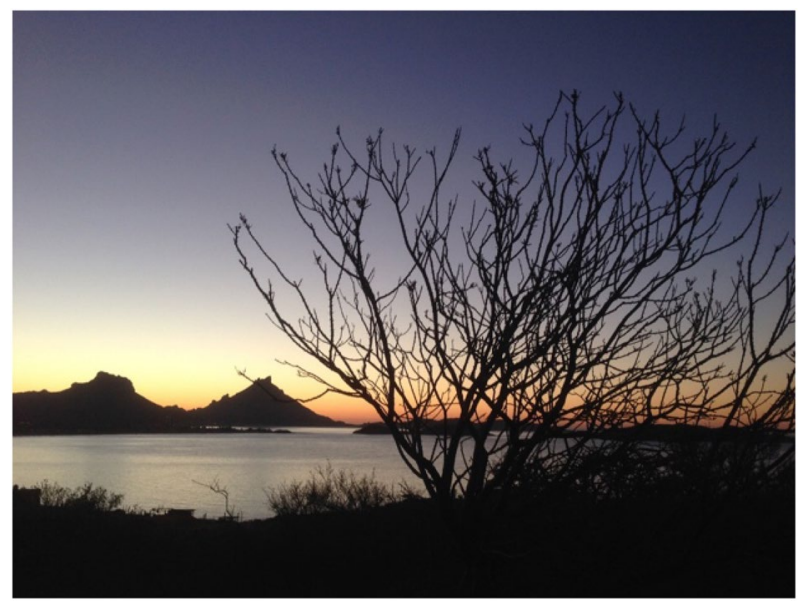

Fig. 14 Photograph by Kee Warner Carrillo 
attend to the processes and dynamics of bordering that are not bound to singular physical or institutional sites. They are thick with consequences for social inequality, human identity, love affairs, violent crime and ecological disruption, to name a few. I entitled this essay "globalizaje somos" because I believe that the borderland communities that already embrace mestizaje are uniquely prepared to engage and lead in an era of globalizaje. We have the words to craft new idiomas-and, quizás, just leave off the italics to invite our readers to code-switch the way we do. We have the experience of creating identities and communities that reach beyond borderlines. We have the eyes to recognize ourselves in the fellow travelers that enter globalizaje from different directions and we have the corazón to care for a público mucho más amplio.

\section{References}

Cantú, F. 2018. The Line Becomes a River: Dispatches from the Border. New York: Riverhead Books. Drexler, J. 2017. Movimiento. Audio CD. Track 1 on Salvavidas de hielo, Warner Brothers Spain. Konrad, V. 2015. Toward a Theory of Borders in Motion. Journal of Borderlands Studies 30 (1): 1-17. Opata Nation/Nación Opata. 2020. Official Website of the Opata Nation. www.opatanation.org. Accessed 18 Sept 2020.

Publisher's Note Springer Nature remains neutral with regard to jurisdictional claims in published maps and institutional affiliations.

Kee Warner Carrillo published research includes a coauthored book, Building Rules: How Local Controls Shape Community Economies and Environments, and articles in sociological and interdisciplinary journals in the United States and abroad. As a Chicano faculty member, Dr. Warner Carrillo has been a leader for diversity and inclusiveness, including serving for ten years as associate vice chancellor for diversity and inclusion. He was a Fulbright Fellow at the Pontificia Universidad Católca de Valparaíso, Chile, in 2001. Following Latin American convention and in tune with the theme of this article, the author writes here under both his family names, father's and mother's. 